\title{
Biological Control Activities of Plant Growth Promoting Rhizobacteria from Organic and Nonorganic Rice Fields against Rice Sheath Blight Pathogen (Rhizoctonia solani Kühn)
}

\author{
Yuniar Harvianti' and Rina Sri Kasiamdari ${ }^{1,2 *}$ \\ ${ }^{1}$ Graduate Program, Faculty of Biology, Universitas Gadjah Mada. Jl.Teknika Selatan, Daerah Istimewa Yogyakarta 55281, Java, Indonesia \\ ${ }^{2}$ Plant Systematics Laboratory, Department of Tropical Biology, Faculty of Biology, Universitas Gadjah Mada. Jl.Teknika Selatan, \\ Daerah Istimewa Yogyakarta 55281, Java, Indonesia
}

Received: March 11, 2021 / Revised: April 13, 2021 / Accepted: April 14, 2021

\begin{abstract}
Rhizoctonia solani is one of the major pathogens that cause sheath blight disease in rice. Sheath blight is one of the most difficult diseases to control. Biological control (with the use of rhizobacteria) is one of the ways to control this disease. Plant Growth Promoting Rhizobacteria (PGPR) is a rhizosphere bacterium that can be used to enhance plant growth. The composition of the rhizobacteria in organic and nonorganic soil is affected by the chemical characteristics of the soil - which influences plant physiology and root exudation patterns. This study aimed to obtain a species of rhizobacteria which shows PGPR activity, from organic and nonorganic rice fields and test their capability to suppress $R$. solani growth. Out of 23 isolates screened for PGPR activity, the following isolates showed high PGPR activity and were selected for in vitro antagonistic activity testing against $R$. solani: ISO6, ISO11, ISO15, ISN2, ISN3, and ISN7, The six isolates produced 43,42-75,23 ppm of IAA, possessed phosphorus solubilization capability, and chitinase-producing activity. ISO6 (54.88\%) and ISN7 (83.33\%) displayed high inhibition capacities against $R$. solani, in vitro. ISO6 and ISN7 inhibited the growth of $R$. solani lesions on rice leaves by $89 \%$ and $100 \%$ (without lesion), respectively, after 7 days of incubation. Analysis of their 16S rRNA sequences revealed that the ISO6 isolate was Citrobacter freundii and ISN7 isolate was Pseudomonas aeruginosa.
\end{abstract}

Keywords: Citrobacter freundii, plant growth promoting rhizobacteria, Pseudomonas aeruginosa, Rhizoctonia solani, biocontrol, rice sheath blight

\section{Introduction}

Rice (Oryza sativa L.) is one of the most important food crop worldwide. The rice production system in the rice fields depends on the quantity of technology intake applied in farming such as selection of varieties, fertilizing, use of pesticides, use of agricultural machinery, and

\section{* Corresponding author}

Tel.: +62274580839

E-mail: rkasiamdari@ugm.ac.id irrigation [1]. Two types of agricultural farming systems are organic system and nonorganic system. Organic farming systems use compost material for fertilization on agricultural land and have a minimum planting time of nine times planting or 3 years with organic fertilization [2]. Organic farming is considered as an agricultural system that is able to provide food availability in a sustainable manner because it is environmentally friendly and produces food that has good quality and is safe for health [1].

The difference in the agricultural model, which is the 
organic and nonorganic farming systems applied will affect the world's biodiversity, including rhizobacteria diversity. Bulluck and Ristaino [3] in their study found that the total population of culturable bacteria, Pseudomonas fluorescence, and enteric bacteria was higher in soil given the addition of organic fertilizer in the second year than in soil with synthetic fertilizer. The research supports the statement that in soil containing organic material, one of which is organic fertilizer with high density will be overgrown with soil microorganisms with high population [4].

The ability of plants to adapt to different environments is largely conditioned by rhizobacteria. Rhizobacteria will increase plant growth with a direct mechanism, which are nutrient availability and nutrient uptake mechanisms by increasing nitrogen fixation, dissolving mineral nutrients, mineralization of organic compounds, production of phytohormones [5] and hydrolytic enzymes [6]. Some of plant-inhabiting microorganisms can suppress plant diseases through competition, predation or antagonism against plant pathogens, or through induction of plant defense systems [7]. Rhizobacteria isolated from plant surface, soil and rhizosphere have been extensively used to improve plant health or increase yield and control major crop diseases caused by various fungal and bacterial diseases [8]. The use of Plant Growth Promoting Bacteria (PGPR) has proved useful in plant-growth promotion and disease control for various crop diseases such as rice disease [9, 10].

Sheath blight is one of the most economically important rice diseases worldwide, which is caused by the fungal pathogen Rhizoctonia solani Kühn. Typical symptoms of this disease are oval to irregular lesions with grayish inner and dark brown margin colors on rice sheath and leaf blades. This fungus leads to the damping of seedlings, black lessions on roots and destroys the stem when plant parts come into contact with the soil [11]. The pathogen can reduce plant growth by rotting the roots and decrease the ability of the plants to take up water and nutrients [12]. $R$. solani can survive in the soil in the form of sclerotium and mycelium, that can make difficult to suppress its spread [13].

Utilization of potential antagonistic microbes originate from rhizosphere areas that have antagonistic power against soil-borne disease through antagonistic mechanisms can be used to overcome problems of rice sheath blight caused by $R$. solani that result in low rice productivity $[14,15]$. Therefore, this research was conducted to isolate PGPR from organic and nonorganic rice fields that have PGPR activity, and to determine the inhibitory activity of PGPR against $R$. solani.

\section{Materials and Methods}

\section{Study area}

Rice rhizosphere sampling was carried out in the agricultural area of Bangun Jaya Village, Tomoni District, East Luwu Regency, South Sulawesi. Soil physical and chemical properties of organic and nonorganic rice fields analyzed include total $\mathrm{C}$, total $\mathrm{N}, \mathrm{C} / \mathrm{N}$ Ratio, $\mathrm{P}_{2} \mathrm{O}_{5}$ and $\mathrm{K}$.

Soil samples were taken from Ciherang rice varieties. The age of rice plants from 25-40 days after planting. Sampling was conducted at the location of organic and nonnorganic rice fields with a depth of 0-20 cm at three points for each. Rice roots were observed at the Microbiology Laboratory, Faculty of Biology, Universitas Gadjah Mada, Yogyakarta.

\section{Isolation of Rhizobacteria}

Rhizosphere soil samples were put $10 \mathrm{~g}$ into the Erlenmeyer flask containing $90 \mathrm{ml}$ of aquadest and homogenized with a shaker for $30 \mathrm{~min}$ at a speed of $100 \mathrm{rpm}$. Soil suspension then let stand for $2 \mathrm{~min}$ [16]. Rhizosphere soil suspension was taken $1 \mathrm{ml}$ and made a series of dilutions up to $10^{-8}$ dilutions, then the last three dilutions were inoculated by the spread plate method on $\mathrm{NA}$ medium. Then incubated for $48 \mathrm{~h}$ at $37^{\circ} \mathrm{C}$. Furthermore, colonies with different characters (macroscopic and microscopic) were observed and purified by the streak plate method on the NA medium to obtain a single colony.

\section{Screening ability of bacteria as Plant Growth Promoting Rhizobacteria (PGPR)}

PGPR activity has been analyzed based on secreting extracellular chitinase enzyme, phosphorus dissolving and producing IAA.

\section{Secretion of extracellular chitinase enzyme}

Chitinase production was tested by inoculating bacterial isolates on chitin agar media containing $0.2 \%$ colloidal chitin and incubated for $48 \mathrm{~h}$ at $24-28^{\circ} \mathrm{C}$. The clear zone 
was formed then calculated chitinolytic index by comparing the diameter of the colony and the diameter of the clear zone as in the following formula:

$$
\text { Citinolitic Index }=\frac{\text { Clear Zone Diameter }}{\text { Colony Bacteria Diameter }}
$$

\section{Phosphorus dissolution test}

Test media was conducted on Pikovskaya's agar with the addition of tri-calcium phosphate (TCP) as a phosphate source [17]. Furthermore, the bacteria were incubated for 3 days at $28^{\circ} \mathrm{C}$. Solubilization index (SI) was calculation according to Premono et al. [18].

\section{IAA ability test}

Bacterial culture was planted in Nutrient Broth medium supplemented with L-tryptophan $\left(5 \mathrm{\mu g} \mathrm{ml}^{-1}\right)$ and incubated at $28^{\circ} \mathrm{C}$ for $48 \mathrm{~h}$. Centrifuged at $3000 \mathrm{rpm}$ for $30 \mathrm{~min}$. Total of $1 \mathrm{ml}$ of the supernatant from the culture was taken and added with $2 \mathrm{ml}$ of the salkwoski reagent $\left(1 \mathrm{ml} 8.12 \% \mathrm{FeCl}_{3.6} \mathrm{H}_{2} \mathrm{O}, 50 \mathrm{ml} 35 \% \mathrm{HClO}_{4}\right.$ in a dark bottle), then incubated at $28^{\circ} \mathrm{C}$ for $25 \mathrm{~min}$. Absorbance readings were carried out at $530 \mathrm{~nm}$ using a spectrophotometer. IAA concentrations in each sample were determined by comparison with the IAA standard curve [5]. The red color change indicates the ability of isolates to produce indole suspension.

\section{In vitro antifungal activity of PGPR}

The in vitro inhibition of mycelium growth of $R$. solani by the PGPR was tested on PDA medium. A small block of agar with fungal growth was cut using sterile blade and placed in the $3 \mathrm{~cm}$ from margin of a fresh PDA plate. Test suspension bacteria $\left(>10^{8} \mathrm{cfu} / \mathrm{ml}\right)$ were streaked at $3 \mathrm{~cm}$ from fungal ends of the plate and incubate at $28 \pm 2^{\circ} \mathrm{C}$ for 7 days. The distance of the fungal colony towards and away from the bacterial colony were noted. The percentage of growth inhibition was calculated using the following calculation:

$$
\text { \% Inhibition }=[(\mathrm{R}-\mathrm{r}) / \mathrm{R} \times 100]
$$

Where, $r$ is the distance of the fungal colony opposite the bacterial colony and $\mathrm{R}$ is the maximum distance of the fungal colony away from the bacterial colony [19].

The hyphal morphology of $R$. solani, grown in indirect contact with PGPR isolates with high activities of inhibition, for seven days, was observed and analyzed by Scan- ning Electron Microscopy (SEM). Mycelial samples were fixed in a $4 \%$ glutaraldehyde solution for $24 \mathrm{~h}$ and washed with phosphate buffer $(\mathrm{pH}=7.2)$. Mycelial samples were then dehydrated in a gradient of ethanol $(70 \%$, $80 \%, 90 \%$ and absolute ethanols). Samples were subsequently dried with liquid $\mathrm{CO}_{2}$ for $15 \mathrm{~min}$, incorporated to aluminium stubs and sputter coated with 10-nm gold layer using Denton Desk V sputter coater. The scanning was performed with an accelerating voltage of $20 \mathrm{kV}$ [19].

\section{Rhizoctonia solani inhibition by PGPR on rice leaf}

The leaf was taken from a two-month-old rice plant of the disease susceptible cultivar, and cut into $6 \mathrm{~cm}$-long pieces. The leaf pieces were surface-sterilized with $1 \%$ sodium hypochlorite solution for $1 \mathrm{~min}$ and washed with sterilized aquadest. The sterilized leaf pieces were then placed on PDA in the petri plates. Overnight grown rhiozbacteria culture in NB in a shaking incubator at $28 \pm 2^{\circ} \mathrm{C}$ at $200 \mathrm{rpm}\left(>10^{8} \mathrm{CFU} / \mathrm{ml}\right)$.

Each rhizobacteria cell suspension was spread on leaf surfaces with a sterile cotton swab. A mycelium collected from $R$. solani culture was placed on the center of each leaf piece. Three leaves pieces were treated with each rhizobacteria for three replications. Leaf pieces without any rhizobacteria treatment and those treated with sterilized aquadest were also included as controls. The petri dishes containing rice leaf pieces placed with a mycelium were incubated at $25^{\circ} \mathrm{C}$ for 7 days with $12 \mathrm{~h}$-light period per day [20]. The relative lesion length on a detached leaf piece was calculated using the following way [21]:

$$
\text { Relative Lesion Length }(\%)=\frac{\text { Lesion length }(\mathrm{cm})}{\text { Leaf length }(\mathrm{cm})} \times 100
$$

\section{Moleculer identification of rhizobacteria}

The rhizobacteria isolates with the high activity inhibition of $R$. solani were identified using $16 \mathrm{~S}$ rRNA. Isolates were grown on NB medium and incubated at $120 \mathrm{rpm}$ shaker $\left(28^{\circ} \mathrm{C}\right)$ for $24 \mathrm{~h}$. DNA from isolates of PGPR efficiently extracted. A quick-Zymoclean ${ }^{\text {TM }}$ Gel DNA Recovery Kit miniprep kit (Zymo Research, USA) was used to isolate the bacterial DNA of that culture. 16S rRNA genes were amplified in thermocyler (Eppendorf thermocycler) using 27F (forward primer) dan 1492R (reverse primer) [22] under the following con- 
ditions: initial denaturation at $95^{\circ} \mathrm{C}(1 \mathrm{~min})$, denaturation at $96{ }^{\circ} \mathrm{C}(15 \mathrm{sec})$, annealing at $52^{\circ} \mathrm{C}(30 \mathrm{sec})$, and extension at $72^{\circ} \mathrm{C}(45 \mathrm{sec})$ and hold $4{ }^{\circ} \mathrm{C}$. The process of PCR (denaturation, annealing and extension) were conducted for 35 cycles. Products reinforced were checked for purity was migrated on a $2 \%$ agarose gel by electrophoresis technique at $100 \mathrm{~V}$ for $60 \mathrm{~min}$. The DNA sequences obtained were analyzed with basic sequence alignment BLAST program and were run against the database from NCBI (National Center for Biotechnology Information Blast) at http://blast.ncbi.nlm.nih.gov. The phylogenetic tree was constructed on the aligned datasets using the maximum likelihood method implemented in the program MEGA version $\mathrm{X}$.

\section{Statistical analysis}

All of the experiments of inhibition of $R$. solani were repeated thrice under identical conditions. A one-way ANOVA (analysis of variance) was applied to confirm the significance of the data according to Duncan's multiple range test (DMRT) at $p \leq 0.05$ using SPSS 21 software.

\section{Results and Discussion}

\section{Isolation of rhizobacteria and soil analysis from organic and nonorganic of rice field}

Twenty-three rhizobacteria have been isolated from organic and nonorganic rice fields had PGPR activity. Fifteen isolates of rhizobacteria (ISO1, ISO2, ISO3, ISO4, ISO5, ISO6, ISO7, ISO8, ISO9, ISO10, ISO11, ISO12, ISO13, ISO14, and ISO15 isolates) were obtained from organic rice fields, while eight rhizobacteria isolates (ISN1, ISN2, ISN3, ISN4, ISN5, ISN6, ISN7,

Table 1. Functional diversity of rice plant rhizosphere bacteria from organic and nonorganic rice fields.

\begin{tabular}{|c|c|c|c|c|c|c|c|}
\hline PGPR Isolates & Gram Stain & $\begin{array}{l}\text { Shape of } \\
\text { Bacteria }\end{array}$ & $\begin{array}{c}\text { Colony Colour on } \\
\text { Nutrient } \\
\text { Agar }\end{array}$ & $\begin{array}{c}\text { Colony size/ shape on } \\
\text { Nutrient Agar }\end{array}$ & $\begin{array}{l}\text { Chitinase } \\
\text { Production }\end{array}$ & $\begin{array}{c}\text { Phosphate } \\
\text { solubilization } \\
\text { ability }\end{array}$ & $\begin{array}{c}\text { IAA } \\
\text { production } \\
(\mathrm{ppm})\end{array}$ \\
\hline ISO1 & Negative & Bacilli & Light yellow & Small/irreguler & - & - & 6.27 \\
\hline ISO2 & Negative & Bacilli & Light white & Large/rhizoid & - & - & 20.66 \\
\hline $\mathrm{ISO}$ & Positive & Bacilli & Off white & Moderate/circular & - & $+/ 1.25$ & 20.23 \\
\hline ISO4 & Negative & Streptobacilli & Off white & Small/circular & - & $+/ 1.2$ & 23.85 \\
\hline ISO5 & Positive & Bacilli & White & Moderate/rhizoid & - & $+/ 1.3$ & 20.06 \\
\hline ISO6 & Negative & Coccobacilli & Off white shiny & Small/circular & $+/ 2.23$ & $+/ 1.76$ & 63.42 \\
\hline 1507 & Positive & Bacilli & Light white & Large/filamentous & $+/ 1.4$ & $+/ 1.47$ & 43.42 \\
\hline ISO8 & Positive & Streptobacilli & Off white & Moderate/irreguler & $+/ 1.2$ & - & 33.08 \\
\hline ISO9 & Positive & Bacilli & White & Moderate/punciform & - & $+/ 1.34$ & 21.52 \\
\hline ISO10 & Negative & Bacilli & Light white & Small/circular & $+/ 1.2$ & $+/ 1.42$ & 21.87 \\
\hline ISO11 & Positive & Diplobacilli & White & Moderate/circular & $+/ 2.1$ & $+/ 1.25$ & 46.78 \\
\hline ISO12 & Negative & Bacilli & White & Small/circular & $+/ 1.13$ & - & 32.90 \\
\hline ISO13 & Negative & Bacilli & Light yellow & Moderate/circular & - & - & 19.02 \\
\hline ISO14 & Negative & Streptobacilli & Light brown & Moderate/circular & - & - & 18.68 \\
\hline ISO15 & Positive & Bacilli & Light yellow & Small/circular & $+/ 2.26$ & $+/ 1.2$ & 43.85 \\
\hline ISN1 & Negative & Coccus & Yellow & Moderate/circular & - & - & 40.40 \\
\hline ISN2 & Positive & Diplobacilli & Light green & Small/circular & $+/ 2.2$ & - & 75.23 \\
\hline ISN3 & Negative & Bacilli & Light brown & Large/irregular & $+/ 1.76$ & $+/ 2.97$ & 68.51 \\
\hline ISN4 & Negative & Bacilli & Light yellow & Small/circular & - & - & 25.15 \\
\hline ISN5 & Positive & Streptococcus & Light yellow & Small/circular & - & - & 72.73 \\
\hline ISN6 & Positive & Streptobacilli & White & Small/circular & $+/ 1.73$ & $+/ 3.86$ & 51.09 \\
\hline ISN7 & Negative & Streptobacilli & Shiny green & Large/punciform & $+/ 2.43$ & $+/ 2.05$ & 72.73 \\
\hline ISN8 & Negative & Coccobacilli & Yellow & Large/irreguler & $+/ 1.43$ & $+/ 2.01$ & 70.23 \\
\hline
\end{tabular}




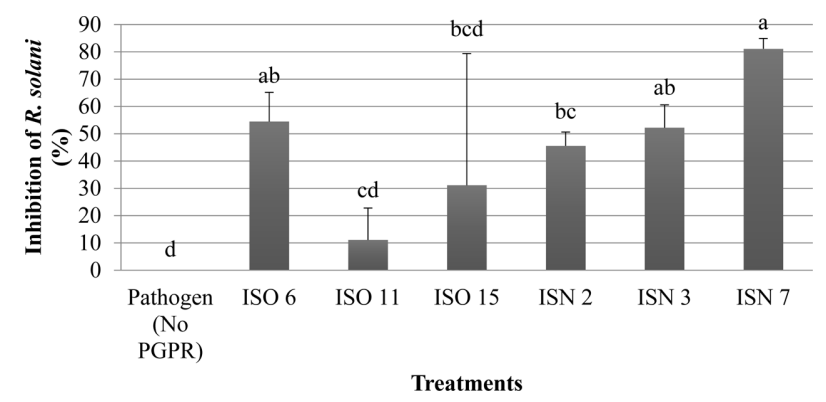

Fig. 1. Effect of Rhizobacteria on inhibition of $R$. solani mycelium in vitro. Values followed by different alphabets indicate statistically significant difference between treatment (DMRT test; $p \leq 0.05$ ).

ISN8) were isolated from nonorganic rice fields showed different macroscopic and microscopic characters (Table 1). The two fields have differences in the inhibition of disease-causing pathogens. Organic rice fields have a higher inhibitory against plant pathogens due to the high organic matter content compared to non-organic rice fields. Bulluck and Ristaino [3] reported that $R$. solani as a soil-borne pathogen can be suppressed by the addition of compost, because it contains various groups of bacteria, including those that are antagonistic to the R. solani.

In this study, rhizobacteria from organic rice fields were more diverse than those from nonorganic fields. Santoso et al. [2] reported that ten colonies from organic and nonorganic rice fields obtained showed different morphological variations, nine of those were from the organic rice field. These results (Table 2) are in accordance with previous findings that soils containing high density organic matter produce microorganisms with high population [4]. The benefical microorganisms in these conditions can play an optimal role in maintaining the balance of the ecosystem naturally [3]. Degens et al. [23] explains that low levels carbon in organic soil can cause a decrease in the metabolic diversity of soil microbes and only certain microbes can grow and multiply.

Based on the results of the analysis of the two soil samples from organic and nonorganic rice fields, the $\mathrm{C} / \mathrm{N}$ ratio in organic rice fields is low when compared to nonorganic rice fields. The average $\mathrm{C} / \mathrm{N}$ ratio for organic and nonorganic rice fields was 18,4433 and 34,0795 , respectively. The $\mathrm{C} / \mathrm{N}$ ratio is a measure of the decomposition process of organic matter, while bacteria are a component that carries out its decomposition activities. The value of the $\mathrm{C} / \mathrm{N}$ ratio is a very sensitive indicator to see the condition of soil fertility [24]. The higher the $\mathrm{C} / \mathrm{N}$ ratio value, the slower the rate of decomposition of soil organic matter by microorganisms. The high $\mathrm{C} / \mathrm{N}$ ratio value indicates that the $\mathrm{C}$ value is greater than the $\mathrm{N}$ value, this reflects the relatively low quality of the substrate that has been decomposed. Laboratory incubation studies have demonstrated that addition of litter with high quality (low C:N ratio) [25] or litter with high soluble $\mathrm{C}$ content [26] to soil led to an increase of microbial biomass and activated a copiotrophic microbial community (such as Gram-negative bacteria). Soil C:N ratio can reflect the substrate quality for soil microorganism growtshenh [27]. The lower the $\mathrm{C} / \mathrm{N}$ ratio indicates microbial activity in the soil, so the higher the PGPR activity by rhizobacteria. Lupwayi et al. [28] reported that the application of fungicides in nonorganic rice

Table 2. Soil composition of organic and nonorganic soils.

\begin{tabular}{ccccc}
\hline Sample & Analysis & Sample 1 & Sample 2 & Average \\
\hline Organic Rice field & C & $3.6766 \%$ & $3.6213 \%$ & $3.64895 \%$ \\
& N & $0.1843 \%$ & $0.2138 \%$ & $0.19905 \%$ \\
C/N Ratio & 19.949 & 16.9377 & 18.4433 \\
Nonorganic Rice field & P & $0.1182 \%$ & $0.1168 \%$ & $0.1175 \%$ \\
& K & $0.0411 \%$ & $0.0625 \%$ & $0.0518 \%$ \\
& C & $3.4209 \%$ & $3.5481 \%$ & $3.4845 \%$ \\
& N & $0.1001 \%$ & $0.1044 \%$ & 34.0795 \\
& C/N Ratio & 34.174 & 33.985 & $0.2788 \%$ \\
\hline
\end{tabular}


fields changes the composition of the soil and disrupts the structure and composition of soil microbes, including organisms that are beneficial to plants such as PGPR, bacteria play a role in the nutrient cycle which can decompose organic matter so as to affect soil fertility, regulate plant growth, and inhibits antagonistic microorganisms. Adriano et al. [29] stated that soil with the addition of organic fertilizers would increase soil fertility, microbial PGPR activity and inhibition of plant pathogens. Shen et al. [30] reported that the application of organic fertilizers can also control Fusarium wilt disease in banana fields due to soil microbial populations.

Phosphorus content in organic rice fields has an average value of $0.1175 \%$ while in nonorganic rice fields has an average value of $0.2788 \%$. Degens et al. [23] reported that low $\mathrm{P}$ nutrient status in plants can increase the exudation of organic acids, especially oxalic acid and citric acid. These organic acids are then used by the phosphate solvent microbes as a substrate, so that the population has increased along with the increasing number of these acids.

\section{Screening ability of rhizobacteria as Plant Growth Pro- moting Rhizobacteria (PGPR)}

All isolates that had been tested for PGPR activity showed different production of chitinase, phosphorus dissolving, and IAA production. For all three assays, each rhizobacterial suspensions containing $1 \times 10^{8}$ cells $\mathrm{ml}^{-1}$ were used. Six rhizobacteria isolates were selected with the highest PGPR activity and had three activities including chitinase production, phosphorus dissolving, and IAA production (Table 1). The PGPR promote plant growth through more than one mechanism that includes secretion of variety of growth stimulating hormones and suppression of plant growth retarding agents, that are pathogens. In vitro test of this study showed that all of the six PGPR isolates from rice rhizosphere produce growth promoting hormone IAA (ppm) from the highest to the lowest are 75.23 (ISN2), 72.73 (ISN7), 68.51 (ISN3), 63.42 (ISO6), 46.78 (ISO11) and 43.85 (ISO15). Among six isolates, four showed the ability to convert insoluble $\mathrm{P}$ to dissolve ranging from 1.2 to $2.97 \mathrm{~cm}$ of clear zone. Furthermore the six rhizobacterias have the ability to produce chitinase with diameters $(\mathrm{cm})$ of clear zone produced by these isolates from the highest to the lowest were 2.43 (ISN7), 2.26 (ISO15), 2.23 (ISO6), 2.2 (ISN2), 2.1 (ISN3) and 1.76 (ISN3).

Rhizobacteria have the ability to produce chitinase enzymes, which can carry out hyperparasitic activity, attacking pathogens by secreting enzymes to hydrolyze pathogenic cell walls containing chitin [31]. Chitinase activity has been shown to suppress pathogenic fungi such as Sclerotium rolfiii, F. oxysporum, Phytophthora sp., Rhizoctonia solani, and Pythium ultimum [32].

\section{In vitro antifungal activity of PGPR}

The six plant growth promoting rhizobacteria were isolated and tested for antifungal potential against $R$. solani. Some bacterial isolates were found to be highly inhibitory of $R$. solani growth throught dual culture assay whereas others showed mild activity or no activity at all. This suggests that the mode of action exerted and the type of antifungal metabolites produced by the isolates vary [33]. The activity of inhibitory $R$. solani shown on Table 3.

The results in vitro inhibition of mycelium growth of $R$. solani by the PGPR isolates, ISO6, ISO11, ISO15, ISN2, ISN3 and ISN7 tested on PDA medium are presented in Table 3. Among six isolates, maximum inhibition of $R$. solani mycelial growth was found by ISO6 and
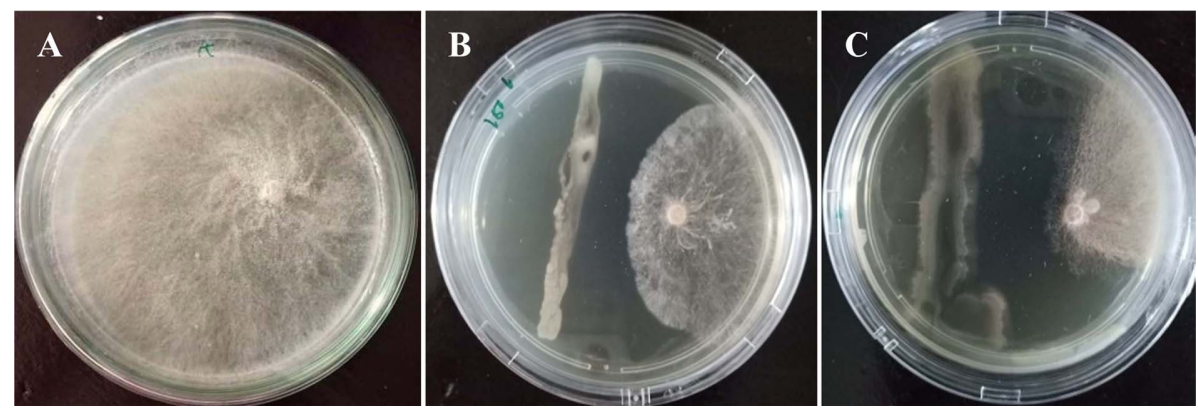

Fig. 2. In vitro antagonism assay. (A) Control, (B) ISO6, (C) ISN7. 
Table 3. Dual culture experiments and index of sheath blight of rice in vitro.

\begin{tabular}{ccc}
\hline Treatment & $\begin{array}{c}\text { In vitro inhibition of } \\
\text { R. solani mycelium on } \\
\text { PDA media } \\
\text { (\% mycelium inhibition) }\end{array}$ & $\begin{array}{c}\text { In vitro Leaf rice } \\
\text { infection rate }(0-5) / \\
\text { Percentage of } \text { R. solani } \\
\text { infection }\end{array}$ \\
\hline Control & - & $0 / 0 \%$ \\
R. solani & 0 & $5 / 100 \%$ \\
ISO6 & 54,66 & $2 / 11 \%$ \\
ISO11 & 11,33 & $4 / 53 \%$ \\
ISO15 & 31,33 & $2 / 22 \%$ \\
ISN2 & 45,66 & $2 / 8 \%$ \\
ISN3 & 52,33 & $2 / 7 \%$ \\
ISN7 & 81,33 & $0 / 0 \%$ \\
\hline
\end{tabular}

ISN7 (Fig. 1). Control plates not treated with the PGPR isolates were completely covered by the phytopathogen showing no inhibition. The ISO6 treated plates showed mycelium inhibition of 54.66\% and ISN7 inhibited mycelium growth by $81.33 \%$ in other words they almost fully inhibit fungal growth (Fig. 2). Observation by SEM showed a curved shape of hyphae by ISO6 and shrunken and lysis of hyphae by ISN7, which suggest the potential of those rhizobacteria to inhibit $R$. solani (Fig. 3). Bormann et al. [34] stated that the inhibitory activity of bacteria can also be built by the amount of chitinase enzyme produced and the type of chitinase produced. The activity of inhibiting fungal growth is also by the ability of bacteria to produce chitin-binding protein (chitinbinding protein).

\section{Rhizoctonia solani inhibition by PGPR on rice leaf}

In vitro results of antagonistic activity rhizobacteria against $R$. solani showed significant effect to control lesion of leaf rice disease (Table 3 ). The inoculation by $R$.

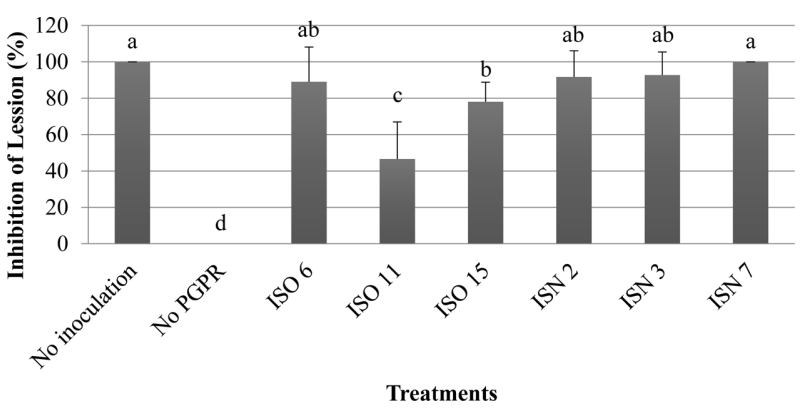

Fig. 4. Effect of Rhizobacteria on inhibition of leaves. Values followed by different alphabets indicate statistically significant difference between treatment (DMRT test; $p \leq 0.05$ ).

solani (without PGPR) showed that leaf rice produced $100 \%$ lesion. Application of PGPR strains with R. solani showed that the PGPR controlled the infection disease at various degrees (Fig. 4). Symptoms of lesions that appear on the leaves included necrotic wounds that were elliptical in shape on the leaf surface, patches that were oval-shaped, gray-green, and long in size [35]. Rhizobacteria have the ability to inhibit the growth of $R$. solani so that it can reduce the severity of symptoms of leaf lesions. ISO6 and ISN7 inhibited lesion growth of $R$. solani on rice leaf by $89 \%$ and $100 \%$, (without lesion), respectively after 7 days of incubation (Fig. 5). The previous assay conducted by Shrestha et al. [20] showed less inhibition of $R$. solani on rice leaf which are $75 \%$ by RAB17S bacterial isolate.

\section{Molecular identification of rhizobacteria}

The Rhizobacteria ISO6 and ISN7 that had highest activity of inhibition of $R$. solani were identified based on the 16S rRNA gene. The results of PCR amplification of 16S rRNA gene from ISO6 isolate produced length fragments of $1427 \mathrm{bp}$, whereas for ISN7 produced $1497 \mathrm{bp}$.
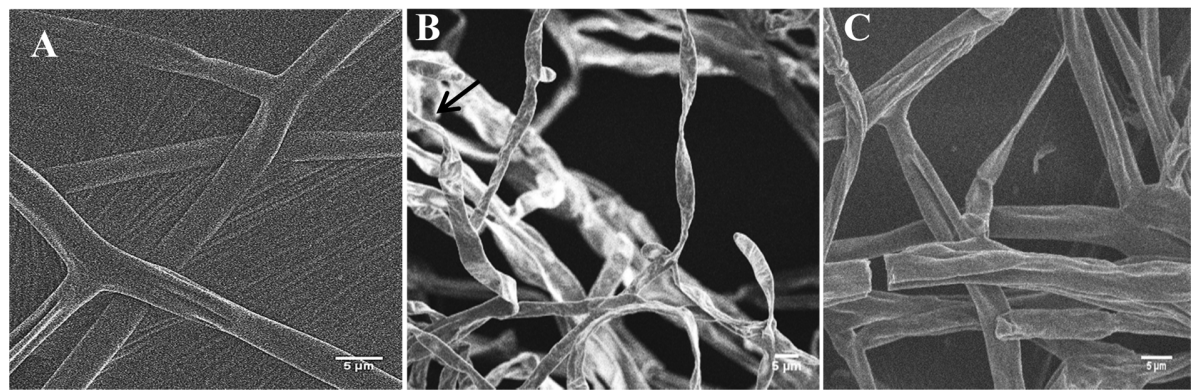

Fig. 3. Scanning electron microscopy of $R$. solani mycelium antagonized with ISO6 and ISN7 isolates after 7 days. Control mycelium $R$. solani (A) was compared with mycelium indirectly exposed to bacteria-inoculated plates ISO6 (B) ISN7 (C). 

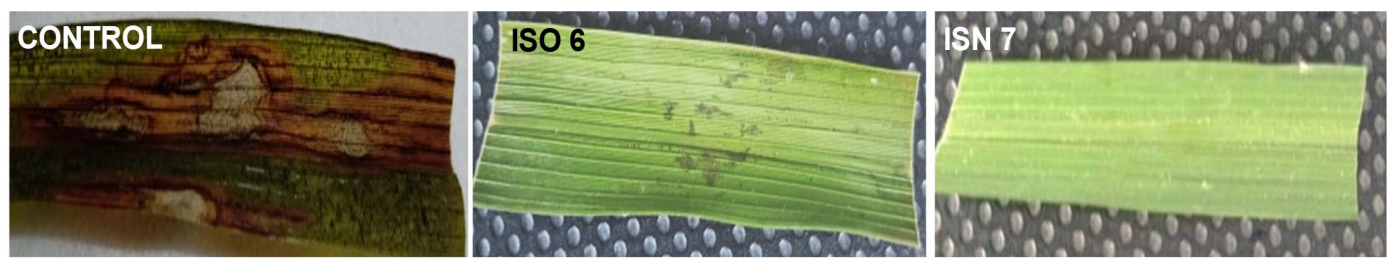

\section{Fig. 5. Inhibition of sheath blight lesion development by ISO6 (89\%) and ISN7 (100\%) after 7 days incubation.}

BLAST results showed that ISO6 isolate had 99.38\% identity with Citrobacter freundii ATCC 8090 (Acc. No. NR_117752.1) and ISN7 isolate had 99.37\% identity with Pseudomonas aeruginosa strain FC1384 (Acc. No. MG871234.1) (data not shown), which were above 99\% and consider as the same species as those available sequences from the NCBI [36]. Phylogenetic tree reconstruction confirmed the identity of the species showed that ISO6 clustered with $C$. freundii strains with the bootstrap value of $91 \%$, whereas ISN7 clustered with $P$. aeruginosa strains with the bootstrap value of $99 \%$. The sequence of ISO6 and ISN7 sequences were not clustered with Bacillus subtilis (Fig. 6). B. subtilis belongs to the class Bacilli, while Pseudomonas and Citrobacter is a member of the Gamma Proteobacteria class. B. subtilis have been reported to have PGPR activity and can be isolated from organic rice fields [2].

C. freundii is commonly found to be a member of the soil microbiome. This microbe is plays an important role in the nitrogen cycle in the environment. $C$. freundii is responsible for reducing nitrate to nitrite in the environment. Some members of the species are nitrogen-fixing and have been found in tissues of living sassafras trees [37]. C. freundii has cellulolytic activity and potential to be used for non-food applications [38]. The growth from previous investigations revealed that the microorganisms such as Citrobacter sp., P. aeruginosa are good to remove heavy metals from contaminated soil [39]. The uptake of lead by microorganisms capable of removing toxic metals from sewage effluents and sludge. Pb-resistant strains of $C$. freundii and $S$. aureus have also been reported [40]. Currently there has never been published

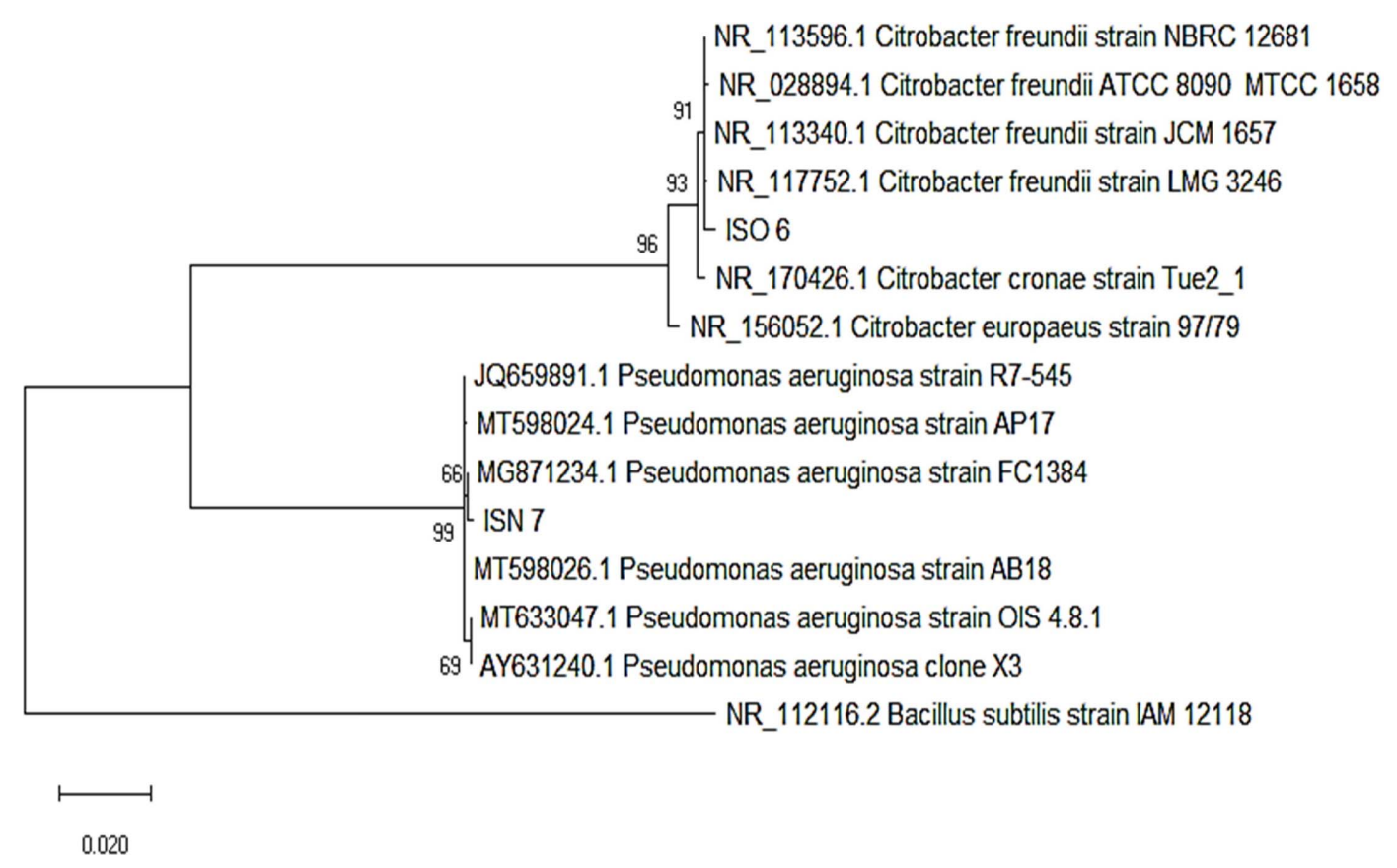

Fig. 6. Phylogenetic tree showing the position of ISO6 and ISN7 isolates compared to its related Cirobacter freundii strain LMG 3246 and Pseudomonas aeruginosa strain FC1384. Numbers at the nodes indicate the percentage of bootstrap values based on 1000 replicates. 
reports about the potential of $C$. freundii as a biocontrol of plant pathogens including $R$. solani. $C$. freundii can be one of the new studies on the potential as biocontrol, especially in inhibition of $R$. solani which causes sheath blight of rice. This research can increase knowledge about other benefits of $C$. freundii.

Mahwish et al. [41] reported that the genera Pseudomonas was the most dominant and most commonly found in various plant studies. Hayat et al. [32] also reported that Bacillus, Enterobacter, Pseudomonas, and Serratia sp. were very good PGPRs with PGP properties such as IAA production, phosphate dissolution, and $\mathrm{N}_{2}$ fixation and were also used for crop production as bioinoculants. Lavakush et al. [42] has reported $P$. aeruginosa shows positive for growth inhibition of $R$. solani with inhibition range was varied from 6 to $15 \mathrm{~mm}$ at 3 and 6 days incubation. Several studies have demonstrated that production of lytic enzyme by Pseudomonas strains was most effective in controlling the plant root pathogens including $F$. oxysporum $\mathrm{f}$. sp ciceris and $R$. solani [43]. In conclusion, ISO6 isolate identified as Citrobacter freundii from organic rice field and ISN7 isolate identified as $P$. aeruginosa from nonorganic rice field appears to be the most potential biocontrol agents for $R$. solani, the pathogen of rice sheath blight with inhibition of sheath blight symptom on rice leaves by 89 to $100 \%$.

\section{Acknowledgments}

This research was financially supported by 'Rekognisi Tugas Akhir (RTA) 2020' Grant from Universitas Gadjah Mada (UGM), Indonesia (No. 2488/UN1.P.II/DIT-LIT/PT/2020). The author would like to thank the entire technicians in Microbiology and Falitma Laboratory, Faculty of Biology, Universitas Gadjah Mada for their help to use of laboratory equipment.

\section{Conflict of Interest}

The authors have no financial conflicts of interest to declare.

\section{References}

1. Savary S, Willocquet L, Elazegul FA, Castilla NP, Teng PS. 2000. Rice pest constrain in tropical Asia: Quantification of yield losses due to rice pest in range of production situations. Plant Dis. 84: 357-369.

2. Santosa S, Sutarno S, Purwanto EDI, Sajidan S. 2018. Molecular characterization of plant growth promoting rhizobacteria using
$16 \mathrm{~S}$ rRNA sequences in the organic rice field of Sukorejo Village, Central Java, Indonesia. Biodiversitas 19: 2157-2162.

3. Bulluck LR III, Ristaino JB. 2002. Effect of synthetic and organic soil fertility amendment on southern blight, soil microbial communities, and yield of processing tomato. Phytopathology 92: 181-189.

4. Wolfe DW. 2001. Tales from the Underground: A Natural History of Subterannean Life. pp. 221. Perseus Publishing, Cambridge, Massachusetts, USA.

5. Gupta G, Parihar SS, Ahirwar NK, Snehi SK, Singh V. 2015. Plant Growth Promoting Rhizobacteria (PGPR): Current and future prospects for development of sustainable agriculture. J. Microbiol. Biochem. Technol. 7: 96-102.

6. Van Loon LC, Beker P, Pieterse C. 1998. Systemic resistance induced by rhizobacteria. Ann. Rev. Phytopathol. 36: 453-483.

7. Compant S, Duffy B, Nowak J, Clement C, Barka EA. 2005. Use of plant growth promoting bacteria for biocontrol of plant diseases: principles, mechanisms of action, and future prospects. Appl. Environ. Microbiol. 71: 4951-4959.

8. Kazempour MN. 2004. Biological control of Rhizoctonia solani, the causal agent of rice sheath blight by antagonistic bacteria in greenhouse and field conditions. Plant Pathol. J. 3: 88-96.

9. Weller DM. 1988. Biological control of soil borne plant pathogens in rhizosphere with bacteria. Ann. Rev. Phytopathol. 26: 379-407.

10. Dilantha F, Nakkeeran S, Yilan Z. 2006. Biosynthesis of Antibiotics by PGPR and Its Relation in Biocontrol of Plant Diseases. pp. 67-109. PGPR Biocontrol Biofert.

11. Garcia VG, Onco MP, Susan VR. 2006. Review. Biology and systematics of the form genus Rhizoctonia. Spanish J. Agric. Res. 4 : 55-79.

12. Wallwork H. 1996. Cereal Root and Crown Diseases Kondinin Group Perth Australia, pp. 14-16.

13. Smith JD, Kidwell KK, Evans MA, Cook RJ, dan Smiley RW. 2003. Assesment of spring wheat genotypes for disease reaction to Rhizoctonia solani AG 8 in controlled environment and directseeded field evaluation. Crop Sci. 43: 694-700.

14. Rao S. 1982. Soil Microorganism and Plant Growth. Science Publisher Inc. USA.

15. Guo Q, Kamio A, Sharma BS, Sagara Y, Arakawa M, Inagaki K. 2006. Survival and subsequent of rice sclerotial diseases fungi, Rhizoctonia oryzae and Rhizoctonia oryzae-sativae, in paddy fields. Plant Dis. 90: 615-622.

16. Cindy DCB, Sarde CO, Bert V, Tarnaud E, Cochet N. 2012. A standardized method for the sampling of rhizosphere and rhizoplane soil bacteria associated to a herbaceous root system. Ann. Microbiol. 6: 471-476.

17. Thakuria D, Talukdar NC, Goswami C, Hazarika S, Boro RC, Khan MR. 2004. Characterization and screening of bacteria from rhizosphere of rice grown in acidic soils of Assam. Curr. Sci. 86: 978985.

18. Premono ME, Moawad AM, Vlek PLG. 1996. Effect of phosphate solubilizing Pseudomonas putida on the growth of maize and its survival in the rhizosphere. Indonesian J. Crop Sci. 11: 13-23. 
19. MeÂndez-Bravo A, Cortazar-Murillo EM, Guevara-Avendaño $E$, Ceballos-Luna O, Rodrõ Âguez-Haas B, Kiel-MartõÂnez AL, et al. 2018. Plant growth-promoting rhizobacteria associated with avocado display antagonistic activity against Phytophthora cinnamomi through volatile emissions. PLoS One 13: e0194665.

20. Shrestha BK, Karki HS, Groth DE, Jungkhun N, Ham JH. 2016. Biological control activities of rice-associated Bacillus sp. strains against sheath blight and bacterial panicle blight of rice. PLoS One 11: e0146764.

21. Kumar KVR, Reddy MS, Kloepper JW, Lawrence KS, Groth DE, Miller ME. 2009. Sheath blight disease of rice (Oryza sativa L.)- An overview. Biosci. Biotechnol. Res. Asia 6: 465-480.

22. Marchesi JR, Sato T, Weightman AJ, Martin TA, Fry JC, Hiom SJ, et al. 1998. Design and evaluation of useful bacterium-spesific PCR primers that amplify genes coding for bacterial 165 rRNA. Appl. Environ. Microbiol. 64: 795-799.

23. Degens BD, Vojvodic-Vakovic M. 1999. A sampling strategy to assess the effect of land use on microbial functional diversity in soils. Aust. J. Soil Res. 37: 593-601.

24. Ge S, Xu H, Ji M, Jiang Y. 2013. Characteristics of soil organic carbon, total nitrogen, and $\mathrm{C} / \mathrm{N}$ ratio in Chinese apple orchards. Soil Sci. 3: 213-217.

25. Bastian F, Bouziri L, Nicolardot B, Ranjard L. 2009. Impact of wheat straw decomposition on successional patterns of soil microbial community structure. Soil Biol. Biochem. 41: 262-275.

26. Fanin N, Hättenschwiler S, Fromin N. 2014. Litter fingerprint on microbial biomass, activity, and community structure in the underlying soil. Plant Soil. 379: 79-91.

27. Myrold DD. 1999. Transformations of nitrogen. In: Sylvia DM, Fuhrmann JJ, Hartel PG, Zuberer DS (eds) Principles. Appl. Soil Microbiol. 5: 259-294.

28. Lupwayi NZ, Harker KN, Dosdall LM, Turkington TK, Blackshaw $\mathrm{RE}$, O'Donovan JT, et al. 2009. Changes in functional structure of soil bacterial communities due to fungicide and insecticide applications in canola. Agr. Ecosyst. Environ. 130: 109-114.

29. Adriano MDL, Gutiérrez F, Dendooven L, Salvador-Figueroa D. 2012. Influence of compost and liquid bioferment on the chemical and biological characteristics of soil cultivated with banana (Musa spp. L.). J. Soil Sci. Plant Nutr. 12: 33-43.

30. Shen Z, Zhong S, Wang Y, Wang B, Mei X, Li R, et al. 2013. Induced soil microbial suppression of banana fusarium wilt disease using compost and biofertilizers to improve yield and quality. Eur. J. Soil Biol. 57: 1-8.

31. Joshi M, Shrivastava R, Sharma AK, Prakash A. 2012. Screening of resistant varieties and antagonistic Fusarium oxysporum for biocontrol of Fusarium Wilt of Chilli. Plant Pathol. Microbiol. 3: 134.
32. Hayat R, Ahmed I, Sheirdil RI. 2012. An overview of plant growth promoting rhizobacteria (PGPR) for sustainable agriculture. In Ashraf M, Öztürk M, Ahmad MSA, Aksoy A (eds.). Crop Prod. Agric. Improvement, 3th Ed. Springer, Dordrecht.

33. Williams GE, Asher MJC. 1996. Selection of rhizobacteria for the control of Phythium ultimum and Aphanomyces cochiliodes on sugerbeet seedlings. Crop Prot. 15: 479-486.

34. Bormann C, Baier D, Horr I, Raps C, Berger J, Jung G, et al. 1999. Characterization of a novel, antifungal, chitin-binding protein from Streptomyces tendae Tü901 that interferes with growth polarity. J. Bacteriol. 181: 7421-7429.

35. Wamishe YA, Jia Y, Gebremariam T, Kelsey C, Belmar S, Mulaw T. 2015. Development of practical diagnostic methods for monitoring rice bacterial panicle blight disease and evaluation of rice germplasm for resistance. In: R.J. Norman and K.A.K. Moldenhauer (eds.). B.R. Wells Rice Research Studies 2014. University of Arkansas Agricultural Experiment Station Research Series 626: 109117.

36. Schlaberg R, Simmon KE, Fisher MA. 2012. A systematic approach for discovering novel, clinically relevant bacteria. Emerg. Infect. Dis. 18: $422-430$.

37. Line M. 1990. Identification of nitrogen-fixing enterobacteria from living Sassafras (Atherosperma moschatum Labill.) trees. Plant Soil 125: 149-152.

38. Kurniawan A, Prihanto AA, Sari SP, Kurniawan A, Asriani E, Sambah AB. 2018. Biochemical characterization of cellulolitic bacteria from mangroves weathered wood in Muntok Sub district, West Bangka regency. Jurnal Sumberdaya Akuatik Indopasifik 2: 1-15.

39. Hookoom M, Puchooa D. 2013. Isolation and identification of heavy metals tolerant bacteria from industrial and agricultural areas in Mauritius. Curr. Res. Microbiol. Biotechnol. b: 119-123.

40. Levinson HS, Mahler I. 1998. Phosphatase activity and lead resistance in Citrobacter freundii and Staphylococcus aureus. FEMS Microbiol. Lett. 161: 135-138.

41. Mahwish Z, Abbasi MK, Hameed S, Rahim N. 2015. Isolation and identification of indigenous plant growth promoting rhizobacteria from Himalayan region of Kashmir and their effect on improving growth and nutrient contents of maize (Zea mays L.). Front. Microbiol. 6: 207.

42. Lavakush, Janardan Y, Verma JP. 2012. Isolation and characterization of effective Plant Growth Promoting Rhizobacteria from rice rhizosphere of Indian soil. Asian J. Biol. Sci. 5: 294-303.

43. Ahmad F, Ahmad I, Khan MS. 2008. Screening of free-living rhizopheric bacteria for their multiple plant growth promoting activities. Microbiol. Res. 168: 173-181. 